\title{
Purinergic interplay between erythrocytes and platelets in diabetes-associated vascular dysfunction
}

\author{
Zhichao Zhou' ${ }^{1}$
}

Received: 14 June 2021 / Accepted: 7 July 2021 / Published online: 19 August 2021

(c) The Author(s) 2021

\begin{abstract}
Cardiovascular complications in diabetes are the leading causes for high morbidity and mortality. It has been shown that alteration of purinergic signaling contributes to diabetes-associated cardiovascular complications. Red blood cells (RBCs) and platelets play a fundamental role in regulation of oxygen transport and hemostasis, respectively. Of note, these cells undergo purinergic dysfunction in diabetes. Recent studies have established a novel function of RBCs as disease mediators for the development of endothelial dysfunction in type 2 diabetes (T2D). RBC-released ATP is defective in T2D, which has implication for induction of vascular dysfunction by dysregulating purinergic signaling. Platelets are hyperactive in diabetes. ADP-mediated $\mathrm{P} 2 \mathrm{Y}_{1}$ and $\mathrm{P} 2 \mathrm{Y}_{12}$ receptor activation contributes to platelet aggregation and targeting $\mathrm{P} 2 \mathrm{Y}$ receptors particularly $\mathrm{P} 2 \mathrm{Y}_{12}$ receptor in platelets is effective for the treatment of cardiovascular events. In contrast to other $\mathrm{P} 2 \mathrm{Y}_{12}$ receptor antagonists, platelet-targeting drug ticagrelor has potential to initiate purinergic signaling in RBCs for the beneficial cardiovascular outcomes. It is increasingly clear that altered vascular purinergic signaling mediated by various nucleotides and nucleoside contributes to diabetes-associated vascular dysfunction. However, the contribution of complex purinergic networks between RBCs and platelets to the vascular dysfunction in diabetes remains unclear. This study discusses the possible interplay of RBCs and platelets via the purinergic network for diabetes-associated vascular dysfunction.
\end{abstract}

Keywords ATP $\cdot$ Circulation $\cdot$ Diabetes $\cdot$ Platelet $\cdot$ Purinergic receptor $\cdot$ Red blood cell

\section{Introduction}

Diabetes is an important risk factor for the development of a variety of cardiovascular diseases including atherosclerosis and ischemic heart disease. The vascular complications associated with diabetes are the leading causes for high morbidity and mortality worldwide $[1,2]$. Vascular dysfunction plays a crucial role in the etiology of diabetesinduced vascular complications. This is characterized by imbalances between vasoconstrictor/inflammatory factors such as reactive oxygen species (ROS) or signaling pathways such as nucleot(s)ide-mediated vasoconstrictor purinergic signaling and vasodilator/anti-inflammatory factors such as nitric oxide (NO) or signaling pathways such as nucleot(s) ide-mediated vasodilator purinergic signaling [2]. These

Zhichao Zhou

zhichao.zhou@ki.se

1 Division of Cardiology, Department of Medicine Solna, Karolinska Institutet, Karolinska University Hospital, Stockholm, Sweden substances are released and/or initiated from the cardiovascular wall as well as circulating cells including red blood cells (RBCs) and platelets. The vasoconstrictor/inflammatory net effects of those substances acting on the vascular wall eventually result in vascular dysfunction [1]. Both purinergic $\mathrm{P} 1$ and $\mathrm{P} 2$ receptors are ubiquitously expressed in endothelial cells and smooth muscle cells in the vasculature [2]. It is increasingly clear that altered vascular purinergic signaling mediated by various nucleotides (e.g., ATP and ADP) and nucleoside (adenosine) significantly contributes to diabetes-associated vascular complications [2-5].

RBCs and platelets are the most abundant cells in the circulation, both of which play a fundamental role in cardiovascular homeostasis, due to their diverse functions including gas transportation, hemostasis, thrombosis, coagulation, and vascular regulation $[1,6]$. Emerging studies have shown that RBCs act as disease mediators for the development of endothelial dysfunction in type 2 diabetes (T2D) [1, 7-10]. RBCs serve as ATP pool and release of ATP in response to low oxygen tension plays a crucial role in the regulation of tissue perfusion [11]. Of note, the release of ATP from 
RBCs in diabetes is defective, which results in less vasodilation in isolated muscle arterioles [12]. Of further interest, a recent study demonstrated that altered vascular purinergic signaling is involved in endothelial dysfunction induced by RBCs from patients with T2D [13]. Platelets are hyperactive in diabetes, which could further promote endothelial dysfunction and contribute to enhanced risk of development of atherothrombotic disease in various vasculatures including coronary and cerebral arteries $[14,15]$. One of the important mechanisms of platelet activation is due to ADP-activated purinergic $\mathrm{P} 2 \mathrm{Y}_{1}$ and $\mathrm{P} 2 \mathrm{Y}_{12}$ receptors [14]. Therefore, targeting these receptors in particular $\mathrm{P} 2 \mathrm{Y}_{12}$ receptors have been applied widely in the clinic to cope with the cardiovascular/ thrombotic event [16, 17].

Given both RBCs and platelets of diabetes origin induce endothelial dysfunction and the significant involvement of purinergic signaling in both cell types, whether there is interplay between RBCs and platelets via purinergic signaling (de)activating vascular purinergic signaling for the induction of diabetes-associated vascular complications remains incompletely understood. The present study discusses complex purinergic networks as possible links for an interplay between RBCs and platelets for the development of vascular dysfunction in diabetes.

\section{$\mathrm{RBC}$ and purinergic signaling in diabetes}

RBCs play a fundamental role in cardiovascular homeostasis because of their contribution to vascular function and integrity. $\mathrm{RBCs}$ become dysfunctional in diabetes, as evidenced by reduced NO bioactivity, enhanced oxidative stress, and ATP-mediated altered purinergic signaling [1, 8]. Such alterations may subsequently affect the vascular function and induce cardiovascular complications. Recent studies have revealed a novel function of $\mathrm{RBCs}$ as disease mediators for the development of T2D-associated endothelial dysfunction. It has been shown that RBCs from patients and rodents with T2D induced endothelial dysfunction and exacerbated cardiac ischemia-reperfusion injury $[1,7,13,18]$. Interestingly, the detrimental effect of RBCs on endothelial function seems not to be solely induced by hyperglycemia, as evidenced by that RBCs of T2D patients with improved glycemic control could not attenuate endothelial injury [9]. The mechanisms underlying this potentially important function of RBCs for the development of cardiovascular dysfunction in T2D remain incompletely elucidated and warrant further investigations.

RBCs can release ATP in response to physiological stimuli [11, 12]. This is evidenced in studies that there is substantial ATP release from human RBCs in response to low oxygen tension without detectable hemolysis [12, 19]. In contrast, it is suggested that ATP release from RBCs occurs during cell lysis, which may be physiologically relevant during exercise and hypoxia when intravascular hemolysis of senescent cells is increased [20]. The ATP release in response to low oxygen tension requires increases in cAMP induced by activation of heterotrimeric $\mathrm{G}$ (Gi) proteinstimulated adenylyl cyclase (AC) [11]. ATP is suggested to be transported via pannexin-1 channels [21] (Fig. 1). The role of pannexin-1 in ATP release may need further validations, as one study using pannexin-1 knockout mice shows an unlikely involvement [22]. Once released, ATP can be degraded to ADP and adenosine by various nucleotidases. These adenine nucleotides activate their corresponding purinergic receptors to regulate blood flow and tissue perfusion [2, 11, 23]. RBC-derived ATP can bind to vasodilator $\mathrm{P} 2$ receptors on the endothelium to generate vasodilators and anti-inflammatory factors [e.g., NO and prostacyclin $\left(\mathrm{PGI}_{2}\right)$ ] for subsequent vasodilation [11]. Interestingly, NO and $\mathrm{PGI}_{2}$ interact with $\mathrm{RBCs}$ to inhibit hypoxia-induced ATP release and stimulate $\mathrm{PGI}_{2}$ receptor-mediated ATP release via voltage-dependent anion channels, respectively $[8,11]$. In addition to ATP release, $\mathrm{RBC}$ s express many purinergic receptors including both $\mathrm{P} 1$ and $\mathrm{P} 2$ receptors [24, 25]. $\mathrm{A}_{2 \mathrm{~B}}, \mathrm{P} 2 \mathrm{Y}_{1}, \mathrm{P} 2 \mathrm{Y}_{12}$, and $\mathrm{P} 2 \mathrm{Y}_{13}$ receptors are commonly expressed in $\mathrm{RBCs}$, and the $\mathrm{P} 2 \mathrm{Y}_{13}$ receptors are most abundantly expressed in both RBCs and reticulocytes [24, 25]. ADP can activate $\mathrm{P} 2 \mathrm{Y}_{13}$ receptors in $\mathrm{RBC}$ s to affect cAMP levels leading to inhibition of ATP release [24]. In addition to vasodilation mediated by adenosine acting on adenosine receptors, adenosine is taken up by $\mathrm{RBCs}$ via equilibrative nucleoside transporter 1 (ENT1) for subsequent metabolism $[1,5,26]$ (Fig. 1).

The release of ATP from RBCs is defective in diabetic patients $[11,12]$. One study suggests that such impairment is associated with more senescent RBCs in diabetes [27]. As RBC P2 $Y_{13}$ receptors exert negative feedback effect for ATP release [24], it is of interest to investigate whether this receptor is involved in impairment of the ATP release in diabetes. Of further importance, the impaired ATP release from RBCs is associated with less vasodilation in arteries incubated with RBCs from patients with T2D [12] (Fig. 1). One proposed mechanism is pointed to less activation of ATP/ADP-mediated $\mathrm{P} 2 \mathrm{Y}_{1}$ receptors and subsequent less NO and $\mathrm{PGI}_{2}$ production $[2,11]$. It is possible that less $\mathrm{PGI}_{2}$ production in diabetes further downregulates $\mathrm{PGI}_{2}$ receptormediated ATP release in RBCs. The negative feedback effect of less NO generation in diabetes on ATP release in RBCs remains unclear, however. On the other hand, the impaired vasodilation could be partially attributed to upregulation of vasoconstrictor purinergic receptors activated by RBCs of T2D. This is supported by a recent study showing that vasoconstrictor $\mathrm{A}_{1}$ and $\mathrm{P} 2 \mathrm{X}_{7}$ receptors are involved in endothelial dysfunction induced by RBCs from T2D patients [13] (Fig. 1). However, activation of those vascular purinergic 


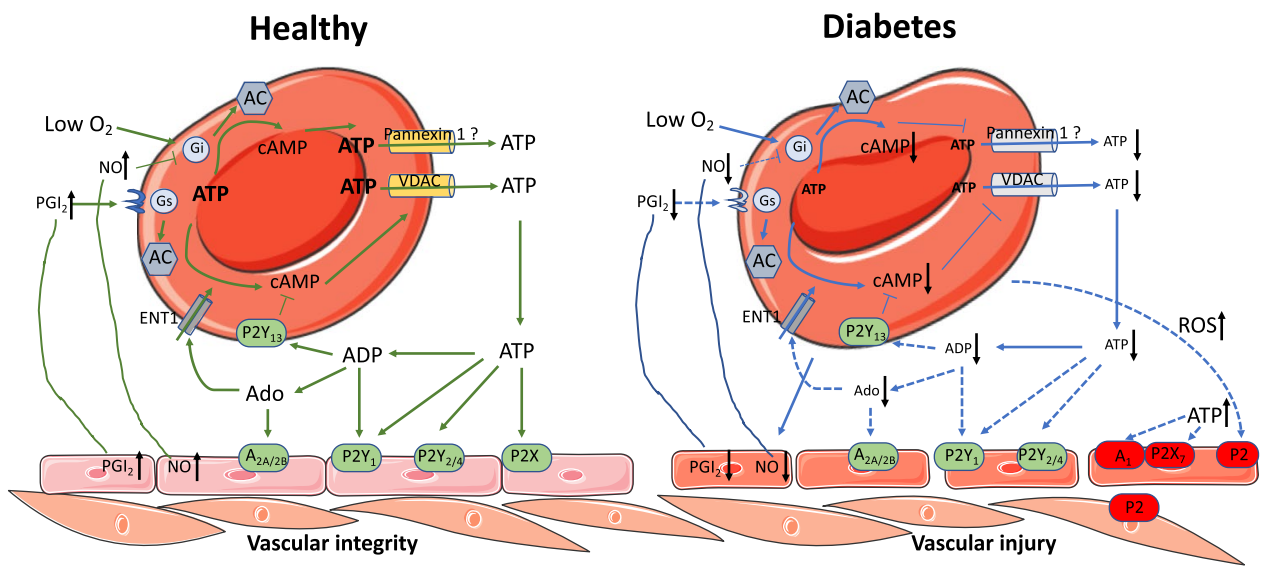

Fig. 1 Red blood cells (RBCs) and purinergic signaling in diabetes. ATP is released from RBCs via voltage-dependent anion channels and likely pannexin 1 . ATP can activate various $\mathrm{P} 2 \mathrm{X}, \mathrm{P} 2 \mathrm{Y}_{1}, \mathrm{P}_{2} \mathrm{Y}_{2}$, and $\mathrm{P}_{2} \mathrm{Y}_{4}$ receptors on the endothelium leading to nitric oxide (NO) and prostacycline $\left(\mathrm{PGI}_{2}\right)$ productions. ATP is degraded to ADP acting on $\mathrm{P}_{2} \mathrm{Y}_{1}$ on the endothelium. The further degradation product adenosine (Ado) activates $\mathrm{A}_{2 \mathrm{~A}}$ and $\mathrm{A}_{2 \mathrm{~B}}$ on the vasculature leading to vasodilation. $\mathrm{NO}$ and $\mathrm{PGI}_{2}$ interact with $\mathrm{RBCs}$ to inhibit hypoxia-induced ATP release and stimulate $\mathrm{PGI}_{2}$ receptor-mediated ATP release, respectively. $\mathrm{ADP}$ activates $\mathrm{P} 2 \mathrm{Y}_{13}$ receptors in $\mathrm{RBCs}$ having negative feedback effect on ATP release. Ado is taken up by equilibrative nucleoside transporter 1 (ENT1) in RBCs for its metabolism. In diabetes, ATP release from RBCs is impaired. Accordingly, the down-

receptors is unlikely due to a direct stimulus of the impaired ATP release from RBCs. The authors speculated that increased ROS formation derived from RBCs in diabetes may stimulate ATP release in other (endothelial) cells than RBCs to activate $\mathrm{P} 2 \mathrm{X}_{7}$ receptors in endothelium and the degraded product adenosine could then activate the vasoconstrictor $A_{1}$ receptors [13]. More studies are needed to elucidate the key purinergic signaling transmitted between the RBCs and vascular wall.

\section{Platelet and purinergic signaling in diabetes}

Platelets play a crucial role in the regulation of hemostasis, thrombosis, coagulation, and vascular function $[6,28]$. A close interaction with vascular wall has been well recognized that platelet activation and the local initiation of the coagulation cascade that lead to thrombus formation are usually observed at the site of vascular injury $[6,14]$. Of note, platelets are hyperactive in diabetes, as is reflected by several dysregulated signaling pathways (e.g., hyperglycemia and oxidative stress) in platelets that lead to an increased tendency to activate and aggregate in response to even a low-grade stimulus $[14,15]$. This leads to the pathology by not only promoting thrombus formation but also causing microvascular embolization and endothelial dysfunction that accelerate progression of local vascular damage [14, 29]. This process regulated ATP and its degradation products affect the corresponding purinergic receptors leading to less vasodilation. Moreover, endothelial dysfunction induced by RBCs of diabetes is through alteration of vascular purinergic $\mathrm{P} 2 \mathrm{X}_{7}$ and $\mathrm{A}_{1}$ receptors. Increased reactive oxygen species (ROS) is speculated to activate vascular ATP release for the activation of vasoconstrictor $\mathrm{P}_{2} \mathrm{X}_{7}$ and $\mathrm{A}_{1}$ receptors. The effects of $\mathrm{NO}$ and $\mathrm{PGI}_{2}$ as well as ADP-mediated $\mathrm{P} 2 \mathrm{Y}_{13}$ activation on ATP release from the RBCs in diabetes remain to be determined. Solid lines indicate established pathways, while dash lines indicate the pathways need to be proved in the future studies. Black arrows toward up indicate increasing effects, while black arrows toward down indicate decreasing effects. Question mark indicates the role that is currently under controversy

significantly contributes to diabetes-associated cardiovascular events such as myocardial infarction and stroke [30].

One of the mechanisms underlying platelet activation has been shown to be due to the involvement of ADP-mediated purinergic signaling [6, 31] (Fig. 2). Several purinergic receptors including $\mathrm{A}_{2 \mathrm{~A}}, \mathrm{~A}_{2 \mathrm{~B}}, \mathrm{P} 2 \mathrm{X}_{1}, \mathrm{P}_{2} \mathrm{Y}_{1}$, and $\mathrm{P} 2 \mathrm{Y}_{12}$ receptors are expressed and functional in human platelets [26, 32]. Activation of pannexin-1 in platelets via collagen leads to an exchange of calcium and ATP [30]. Extracellular ATP activates $\mathrm{P} 2 \mathrm{X}_{1}$ receptors leading to platelet shape change through extracellular calcium influx $[4,31]$. ATP is subsequently degraded to ADP and adenosine [31]. ADP exerts a positive feedback on platelet reactivity. Activation of the $\mathrm{P} 2 \mathrm{Y}_{1}$ receptor in response to ADP leads to shape change and initiation of platelet aggregation. The activation of $\mathrm{P} 2 \mathrm{Y}_{1}$ receptors stimulates phospholipase C (PLC)-inositol triphosphate (IP3) axis leading to mobilization of intracellular calcium [31]. ADP-activated $\mathrm{P}_{2} \mathrm{Y}_{1}$ receptors also exert synergistic effect to potentiate the ATP-P2 $\mathrm{X}_{1}$ receptor-mediated action $[4,31]$. In addition to activating $P 2 Y_{1}$ receptors, ADP activates Gi-coupled $\mathrm{P} 2 \mathrm{Y}_{12}$ receptors resulting in stabilization of platelet aggregation [31]. The Goi2 subunit inhibits $\mathrm{AC}$, thereby reducing cAMP levels. Although inhibition of $\mathrm{AC}$ is a key feature of platelet activation by ADP, this process has no causal relationship to platelet aggregation [33]. There is a complex signaling interaction between $\mathrm{P}_{2} \mathrm{Y}_{1}$ and $\mathrm{P} 2 \mathrm{Y}_{12}$ receptors. Activation of $\mathrm{P} 2 \mathrm{Y}_{12}$ receptors positively 


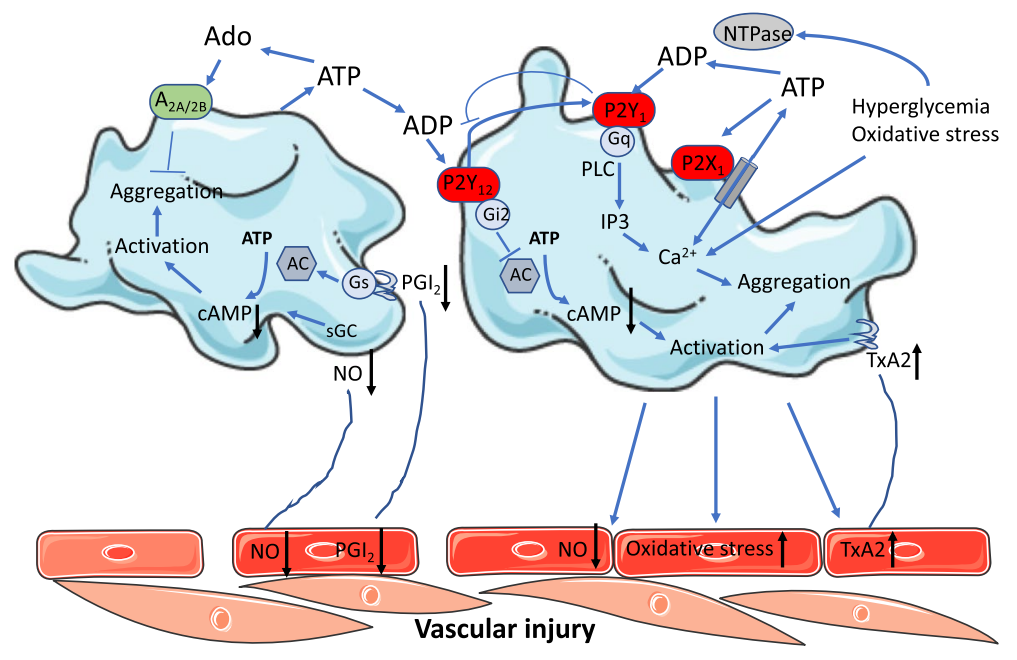

Fig. 2 Platelets and purinergic signaling in diabetes. Platelets release ATP upon stimulation by hyperglycemia or oxidative stress via pannexin 1, which is subsequently degraded to ADP and adenosine (Ado). ATP and ADP activate $\mathrm{P}_{2} \mathrm{X}_{1}$ and $\mathrm{P} 2 \mathrm{Y}_{1}$ receptors leading to increase in calcium concentration and platelet aggregation. ADP activates $\mathrm{P} 2 \mathrm{Y}_{12}$ receptors resulting in platelet activation and stabilization of platelet aggregation. Activation of $\mathrm{P} 2 \mathrm{Y}_{12}$ receptors positively regulates $\mathrm{P}_{2} \mathrm{Y}_{1}$ receptor-mediated action, while activation of $\mathrm{P} 2 \mathrm{Y}_{1}$ receptors negatively regulates the effect of $\mathrm{P}_{2} \mathrm{Y}_{12}$ receptors. In contrast, Ado exerts inhibitory effects on platelet activation via $A_{2 A}$ and

regulates $\mathrm{P} 2 \mathrm{Y}_{1}$ receptor-mediated action, while activation of $\mathrm{P} 2 \mathrm{Y}_{1}$ receptors negatively regulates the effect of $\mathrm{P} 2 \mathrm{Y}_{12}$ receptors [34]. In contrast, adenosine could exert inhibitory effects on platelet activation via $\mathrm{A}_{2 \mathrm{~A}}$ and $\mathrm{A}_{2 \mathrm{~B}}$ receptors resulting in increased cAMP formation mainly during tissue injury and inflammation [26, 31] (Fig. 2).

Accumulative evidence has shown an alteration of purinergic components in platelets in diabetes (Fig. 2). Platelet ATP and ADP levels from patients with diabetes were higher than in platelets from healthy subjects [35]. Stimulation with thrombin in those platelets caused greater release of ATP and ADP than in the healthy group [35]. Significant correlations between platelet ATP/ADP and platelet activities have been found in diabetic patients [35]. There are also more abundantly expressed $\mathrm{P} 2 \mathrm{Y}_{1}$ and $\mathrm{P} 2 \mathrm{Y}_{12}$ receptors in platelets in diabetes [15]. Nucleoside triphosphate diphosphohydrolase (NTPDase), an enzyme that hydrolyzes ATP and ADP, was found to be elevated in platelet-rich plasma preparations from diabetic patients and rats [36-41]. Studies on the role for 5'-nucleotidase that degrades AMP to adenosine are not consistent. The enzyme activity in diabetes was observed to be decreased [36], unaltered [41], or increased [37-40]. Adenosine deaminase was found to be either increased or unaltered in platelets of diabetic rats [36, 38]. There is also evidence showing hyperglycemia has direct impact on ATP, ADP, and AMP hydrolysis in T2D patients
$\mathrm{A}_{2 \mathrm{~B}}$ receptors. Activity of nucleotidase such as nucleoside triphosphate diphosphohydrolase (NTPase), an enzyme that hydrolyzes ATP and ADP, is elevated. Decreased productions of nitric oxide (NO) and prostacyclin $\left(\mathrm{PGI}_{2}\right)$ in diabetes stimulate platelet activation. On the other hand, activated platelets further promote vascular injury by increasing oxidative stress and thromboxane A2 (TxA2) production and decreasing NO bioavailability. Black arrows toward up indicate increasing effects, while black arrows toward down indicate decreasing effects

[42]. In addition to the platelet activation upon vascular injury, activated platelets in diabetes have shown to cause endothelial dysfunction in healthy vasculature by increasing vascular oxidative stress, thromboxane $\mathrm{A}_{2}$ production, and reducing NO bioavailability [29], suggesting a vicious circle for promoting vascular injury (Fig. 2). However, the functional implications of the altered adenine nucleotides and enzymes in platelets for the diabetes-associated vascular complications remain to be determined.

\section{Interplay between RBCs and platelets}

Platelets have been thought to be the first cells being recruited to the site of vascular injury. However, this was challenged by a study showing that RBCs were the first cells adhering to the injured endothelium/vascular wall followed by recruitment of platelets [43]. Both RBCs and platelets of T2D origin induce vascular injury through increased formation of ROS, decreased NO bioavailability, and possibly altering purinergic signaling [7, 29]. However, the current knowledge regarding the purinergic signaling regulating a functional interaction between RBCs and platelets in the circulation in diabetes is sparse. $\mathrm{NO}$ and $\mathrm{PGI}_{2}$ have been established as potent inhibitors for platelet aggregation [6, 28]. Decreased NO bioactivity and $\mathrm{PGI}_{2}$ from endothelial 
cells and RBCs (likely via impaired ATP release) in diabetes further promote platelet activation (Fig. 3). Platelets are hyperactive in diabetes, which are more sensitive to activation even by a weak stimulation of purines [15]. Despite less ATP/ADP released from RBCs, it can be speculated that platelets could still be activated by impaired RBC-derived ATP and subsequent less degradation product of ADP in diabetes (Fig. 3). In contrast to impairment of ATP release from RBCs, platelet-derived ATP-ADP signaling is enhanced in diabetes, which exerts positive feedback on $\mathrm{P}_{2} \mathrm{Y}_{1}$ and $\mathrm{P} 2 \mathrm{Y}_{12}$ receptors on platelets promoting platelet activation and aggregation [31]. As mentioned above, ATP release from RBCs is defective in diabetes, which results in less vasodilation [2]. It is unlikely that enhanced platelet-derived ATPADP signaling exerts any compensatory or beneficial effects on vascular function, as the overall effect of platelets isolated from diabetic animals is to induce endothelial dysfunction [29]. Instead, enhanced platelet-derived ATP in diabetes may stimulate vascular vasoconstrictor purinergic receptors in the circulation that are upregulated by the dysfunctional RBCs [13] (Fig. 3). More studies are needed to investigate the contribution of enhanced platelet-derived ATP/ADP to the activation of vascular purinergic receptors in diabetes. Moreover, how platelet-derived ADP in diabetes affects $\mathrm{P}_{2} \mathrm{Y}_{13}$ receptors on RBCs for the subsequent ATP release remains unknown and is of interest for further investigations.

Several $\mathrm{P} 2 \mathrm{Y}_{12}$ receptor antagonists like clopidogrel and ticagrelor have been developed and are commonly prescribed to target ADP-mediated $\mathrm{P} 2 \mathrm{Y}_{12}$ receptor activation in platelets for the treatment of thrombosis, stroke, and myocardial infarction in millions of patients with/without diabetes [16]. In addition to targeting platelets, ticagrelor is the only drug influencing RBCs [26], which may have a great potential to be involved in the interplay between RBCs and platelets. Indeed, ticagrelor can induce substantial amount of ATP release from $\mathrm{RBCs}$ by changing the membrane potential of RBCs, which are inhibited by anion transporter inhibitors 5-nitro-2-(3-phenylpropylamino)benzoic acid (NPPB) and probenecid [44]. Although $\mathrm{P}_{2} \mathrm{Y}_{12}$ receptors are present in the human RBCs [24], it remains unknown whether ticagrelor could activate $\mathrm{P} 2 \mathrm{Y}_{12}$ receptors in $\mathrm{RBCs}$ for the ATP release. Of further interest, ticagrelor can target RBC ENT1 to inhibit adenosine uptake by RBCs, thereby increasing concentration of adenosine in the circulation [45]. Through

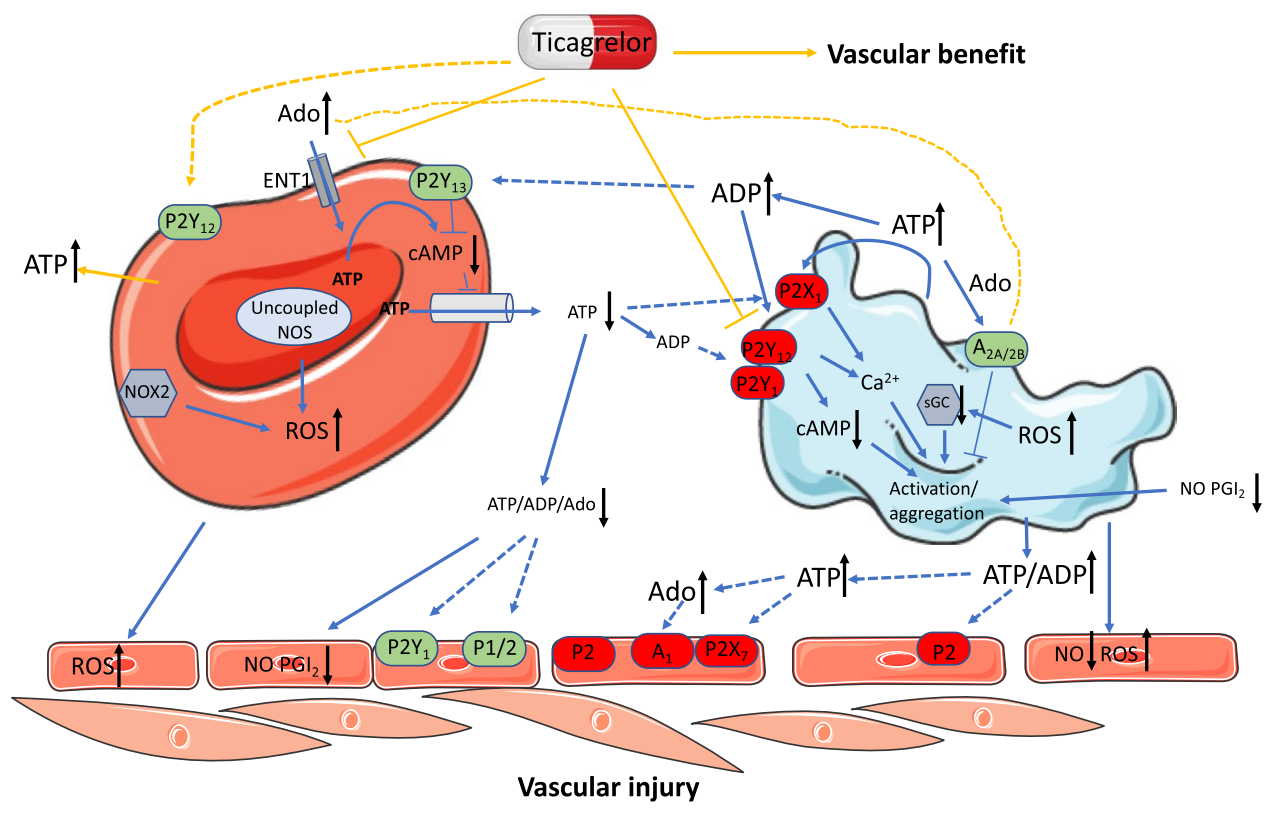

Fig. 3 Interplay between RBCs and platelets in diabetes. ATP release from RBCs in diabetes is defective, which together with its degradation products induces less vasodilation. Platelets become sensitive to stimuli in diabetes; the less amount of ATP and ADP derived from RBCs may still activate platelets via $\mathrm{P} 2 \mathrm{X}_{1}, \mathrm{P} 2 \mathrm{Y}_{1}$, and $\mathrm{P} 2 \mathrm{Y}_{12}$ receptors. Decreased bioavailability of nitric oxide (NO) and prostacyclin $\left(\mathrm{PGI}_{2}\right)$ and increased reactive oxygen species (ROS) from endothelial cells as well as RBCs could promote platelet activation. Enhanced platelet-derived purine/adenosine (Ado) may activate vasoconstrictor purinergic receptors (e.g., $\mathrm{A}_{1}$ and $\mathrm{P} 2 \mathrm{X}_{7}$ ) upregulated by dysfunctional RBCs resulting in vascular injury. Whether there is a crosstalk between enhanced platelet-derived purine/Ado and $\mathrm{P} 2 \mathrm{Y}_{13}$ receptors in
RBCs remains unclear. Ticagrelor has been thought to mainly target $\mathrm{P} 2 \mathrm{Y}_{12}$ receptors in platelets for platelet aggregation. The pleiotropic cardiovascular effects by ticagrelor in diabetes are proposed to be via its additional actions on ATP release and inhibition of Ado uptake from RBCs. Whether ticagrelor directly activates $\mathrm{P} 2 \mathrm{Y}_{12}$ receptor in RBCs remains to be determined. Solid lines indicate established pathways, while dash lines indicate the pathways need to be proved in the future studies. Black arrows toward up indicate increasing effects, while black arrows toward down indicate decreasing effects. Yellow lines indicate the effects of ticagrelor on purinergic signaling between erythrocytes and platelets in diabetes 
these two pathways, ticagrelor-induced ATP release from RBCs may compensate for the impairment of ATP release from RBCs in T2D, thereby attenuating diabetes-associated vascular complications [26]. On the other hand, ticagrelorinhibited adenosine uptake may counteract the ADP-mediated platelet activation via activation of $\mathrm{A}_{2 \mathrm{~A}}$ and $\mathrm{A}_{2 \mathrm{~B}}$ receptors [46] (Fig. 3). This hypothesis may increase the insights into understanding the potential mechanisms underlying the pleiotropic cardiovascular effects by ticagrelor in diabetes. These beneficial effects include anti-inflammation, increase in NO bioavailability, improvement in endothelial function, and decrease in major adverse cardiovascular event [47-49]. Given the abundance of RBCs and platelets and the active purinergic communication in the circulation, the RBCs and platelets may serve as potential therapeutic targets for the treatment of diabetes-associated vascular complications. The fact that the concentrations of RBCs exceed those of platelets in the circulation may require a higher dose of the future pharmacological agent to achieve an effective effect on RBCs.

\section{Conclusion}

Both RBC- and platelet-derived purinergic signaling play a significant role in the regulation of vascular function in diabetes. There are complex purinergic networks communicating with each other between RBCs and platelets in the vasculature. However, the contribution of purinergic (in) activation derived from dysfunctional RBCs and platelets to the vascular dysfunction in diabetes remains unclear. Experimental studies to evaluate the proposed interaction of purinergic signaling between RBCs and platelets for diabetes-associated vascular dysfunction are warranted. A better understanding of the purinergic communication between these cells will enhance their potentials as targets for the treatment of diabetes-associated vascular complications.

Author contribution Z.Z. conceived and designed the study; Z.Z. wrote and edited the manuscript.

Funding Open access funding provided by Karolinska Institute. This study was supported by the Swedish Heart and Lung Foundation 20190341 and 20200326, the Loo and Hans Ostermans Foundation 2018-01213 and 2020-01209, the Eva and Oscar Alréns Foundation 2021-1233, and the Karolinska Institute grants 2018-01837 and 2020-02285.

Data availability Not applicable.

Code availability Not applicable.

\section{Declarations}

Conflict of interest The author declares no competing interests.

Ethical approval This article does not contain any studies with human participants or animals performed by the author.

Open Access This article is licensed under a Creative Commons Attribution 4.0 International License, which permits use, sharing, adaptation, distribution and reproduction in any medium or format, as long as you give appropriate credit to the original author(s) and the source, provide a link to the Creative Commons licence, and indicate if changes were made. The images or other third party material in this article are included in the article's Creative Commons licence, unless indicated otherwise in a credit line to the material. If material is not included in the article's Creative Commons licence and your intended use is not permitted by statutory regulation or exceeds the permitted use, you will need to obtain permission directly from the copyright holder. To view a copy of this licence, visit http://creativecommons.org/licenses/by/4.0/.

\section{References}

1. Pernow J, Mahdi A, Yang J, Zhou Z (2019) Red blood cell dysfunction: a new player in cardiovascular disease. Cardiovasc Res 115(11):1596-1605. https://doi.org/10.1093/cvr/cvz156

2. Zhou R, Dang X, Sprague RS, Mustafa SJ, Zhou Z (2020) Alteration of purinergic signaling in diabetes: focus on vascular function. J Mol Cell Cardiol 140:1-9. https://doi.org/10.1016/j.yjmcc. 2020.02.004

3. Mahdi A, Jiao T, Tratsiakovich Y, Yang J, Ostenson CG, Pernow J, Zhou Z (2018) Altered purinergic receptor sensitivity in type 2 diabetes-associated endothelial dysfunction and up(4)A-mediated vascular contraction. Int J Mol Sci 19 (12). https://doi.org/10. 3390/ijms19123942

4. Burnstock G (2017) Purinergic signaling in the cardiovascular system. Circ Res 120(1):207-228. https://doi.org/10.1161/CIRCR ESAHA.116.309726

5. Zhang Y, Wernly B, Cao X, Mustafa SJ, Tang Y, Zhou Z (2021) Adenosine and adenosine receptor-mediated action in coronary microcirculation. Basic Res Cardiol 116(1):22. https://doi.org/10. 1007/s00395-021-00859-7

6. Mahdi A, Cortese-Krott MM, Kelm M, Li N, Pernow J (2021) Novel perspectives on redox signaling in red blood cells and platelets in cardiovascular disease. Free Radic Biol Med 168:95-109. https://doi.org/10.1016/j.freeradbiomed.2021.03.020

7. Zhou Z, Mahdi A, Tratsiakovich Y, Zahoran S, Kovamees O, Nordin F, Uribe Gonzalez AE, Alvarsson M, Ostenson CG, Andersson DC, Hedin U, Hermesz E, Lundberg JO, Yang J, Pernow J (2018) Erythrocytes from patients with type 2 diabetes induce endothelial dysfunction via arginase I. J Am Coll Cardiol 72(7):769-780. https://doi.org/10.1016/j.jacc.2018.05.052

8. Zhou Z, Yang J, Pernow J (2018) Erythrocytes and cardiovascular complications. Aging (Albany NY) 10(12):3643-3644. https:// doi.org/10.18632/aging.101688

9. Mahdi A, Jiao T, Yang J, Kovamees O, Alvarsson M, von Heijne M, Zhou Z, Pernow J (2019) The effect of glycemic control on endothelial and cardiac dysfunction induced by red blood cells in type 2 diabetes. Front Pharmacol 10:861. https://doi.org/10.3389/ fphar.2019.00861

10. Mahdi A, Tengbom J, Alvarsson M, Wernly B, Zhou Z, Pernow J (2020) Red blood cell peroxynitrite causes endothelial dysfunction 
in type 2 diabetes mellitus via arginase. Cells 9 (7). https://doi.org/ 10.3390/cells9071712

11. Sprague RS, Ellsworth ML (2012) Erythrocyte-derived ATP and perfusion distribution: role of intracellular and intercellular communication. Microcirculation 19(5):430-439. https://doi.org/10. 1111/j.1549-8719.2011.00158.x

12. Sprague RS, Bowles EA, Achilleus D, Stephenson AH, Ellis CG, Ellsworth ML (2011) A selective phosphodiesterase 3 inhibitor rescues low PO2-induced ATP release from erythrocytes of humans with type 2 diabetes: implication for vascular control. Am J Physiol Heart Circ Physiol 301(6):H2466-2472. https://doi.org/ 10.1152/ajpheart.00729.2011

13. Mahdi A, Tratsiakovich Y, Tengbom J, Jiao T, Garib L, Alvarsson M, Yang J, Pernow J, Zhou Z (2020) Erythrocytes induce endothelial injury in type 2 diabetes through alteration of vascular purinergic signaling. Front Pharmacol 11:603226. https://doi.org/ 10.3389/fphar.2020.603226

14. Kaur R, Kaur M, Singh J (2018) Endothelial dysfunction and platelet hyperactivity in type 2 diabetes mellitus: molecular insights and therapeutic strategies. Cardiovasc Diabetol 17(1):121. https://doi.org/10.1186/s12933-018-0763-3

15. Kakouros N, Rade JJ, Kourliouros A, Resar JR (2011) Platelet function in patients with diabetes mellitus: from a theoretical to a practical perspective. Int J Endocrinol 2011:742719. https://doi. org/10.1155/2011/742719

16. Samos M, Fedor M, Kovar F, Mokan M, Bolek T, Galajda P, Kubisz P, Mokan M (2016) Type 2 diabetes and ADP receptor blocker therapy. J Diabetes Res 2016:6760710. https://doi.org/ $10.1155 / 2016 / 6760710$

17. Wernly B, Zhou Z (2020) More purinergic receptors deserve attention as therapeutic targets for the treatment of cardiovascular disease. Am J Physiol Heart Circ Physiol. https://doi.org/10.1152/ ajpheart.00417.2020

18. Yang J, Zheng X, Mahdi A, Zhou Z, Tratsiakovich Y, Jiao T, Kiss A, Kovamees O, Alvarsson M, Catrina SB, Lundberg JO, Brismar K, Pernow J (2018) Red blood cells in type 2 diabetes impair cardiac post-ischemic recovery through an arginase-dependent modulation of nitric oxide synthase and reactive oxygen species. JACC Basic Transl Sci 3(4):450-463. https://doi.org/10.1016/j. jacbts.2018.03.006

19. Sprague RS, Goldman D, Bowles EA, Achilleus D, Stephenson AH, Ellis CG, Ellsworth ML (2010) Divergent effects of low-O(2) tension and iloprost on ATP release from erythrocytes of humans with type 2 diabetes: implications for $\mathrm{O}(2)$ supply to skeletal muscle. Am J Physiol Heart Circ Physiol 299(2):H566-573. https:// doi.org/10.1152/ajpheart.00430.2010

20. Sikora J, Orlov SN, Furuya K, Grygorczyk R (2014) Hemolysis is a primary ATP-release mechanism in human erythrocytes. Blood 124(13):2150-2157. https://doi.org/10.1182/ blood-2014-05-572024

21. Lohman AW, Billaud M, Isakson BE (2012) Mechanisms of ATP release and signalling in the blood vessel wall. Cardiovasc Res 95(3):269-280. https://doi.org/10.1093/cvr/cvs187

22. Keller AS, Diederich L, Panknin C, DeLalio LJ, Drake JC, Sherman R, Jackson EK, Yan Z, Kelm M, Cortese-Krott MM, Isakson BE (2017) Possible roles for ATP release from RBCs exclude the cAMP-mediated Panx1 pathway. Am J Physiol Cell Physiol 313(6):C593-C603. https://doi.org/10.1152/ajpcell.00178.2017

23. Cai Z, Tu L, Guignabert C, Merkus D, Zhou Z (2020) Purinergic dysfunction in pulmonary arterial hypertension. J Am Heart Assoc:e017404. https://doi.org/10.1161/JAHA.120.017404

24. Wang L, Olivecrona G, Gotberg M, Olsson ML, Winzell MS, Erlinge D (2005) ADP acting on P2Y13 receptors is a negative feedback pathway for ATP release from human red blood cells.
Circ Res 96(2):189-196. https://doi.org/10.1161/01.RES.00001 53670.07559.E4

25. Sun K, Liu H, Song A, Manalo JM, D’Alessandro A, Hansen KC, Kellems RE, Eltzschig HK, Blackburn MR, Roach RC (1985) Xia Y (2017) Erythrocyte purinergic signaling components underlie hypoxia adaptation. J Appl Physiol 123(4):951-956. https://doi. org/10.1152/japplphysiol.00155.2017

26. Wernly B, Erlinge D, Pernow J, Zhou Z (2021) Ticagrelor: a cardiometabolic drug targeting erythrocyte-mediated purinergic signaling? Am J Physiol Heart Circ Physiol 320(1):H90-H94. https://doi.org/10.1152/ajpheart.00570.2020

27. Subasinghe W, Spence DM (2008) Simultaneous determination of cell aging and ATP release from erythrocytes and its implications in type 2 diabetes. Anal Chim Acta 618(2):227-233. https://doi. org/10.1016/j.aca.2008.04.061

28. van der Meijden PEJ, Heemskerk JWM (2019) Platelet biology and functions: new concepts and clinical perspectives. Nat Rev Cardiol 16(3):166-179. https://doi.org/10.1038/ s41569-018-0110-0

29. Ishida K, Taguchi K, Matsumoto T, Kobayashi T (2014) Activated platelets from diabetic rats cause endothelial dysfunction by decreasing Akt/endothelial NO synthase signaling pathway. PLoS ONE 9(7):e102310. https://doi.org/10.1371/journal.pone. 0102310

30. Chatterjee M, Ehrenberg A, Toska LM, Metz LM, Klier M, Krueger I, Reusswig F, Elvers M (2020) Molecular drivers of platelet activation: unraveling novel targets for anti-thrombotic and antithrombo-inflammatory therapy. Int J Mol Sci 21 (21). https://doi. org/10.3390/ijms21217906

31. Burnstock G (2015) Blood cells: an historical account of the roles of purinergic signalling. Purinergic Signal 11(4):411-434. https:// doi.org/10.1007/s11302-015-9462-7

32. Wang L, Ostberg O, Wihlborg AK, Brogren H, Jern S, Erlinge D (2003) Quantification of ADP and ATP receptor expression in human platelets. J Thromb Haemost 1(2):330-336. https://doi.org/ 10.1046/j.1538-7836.2003.00070.x

33. Cattaneo M (2011) Bleeding manifestations of congenital and drug-induced defects of the platelet P2Y12 receptor for adenosine diphosphate. Thromb Haemost 105(Suppl 1):S67-74. https://doi. org/10.1160/THS10-11-0742

34. Hardy AR, Jones ML, Mundell SJ, Poole AW (2004) Reciprocal cross-talk between $\mathrm{P} 2 \mathrm{Y} 1$ and $\mathrm{P} 2 \mathrm{Y} 12$ receptors at the level of calcium signaling in human platelets. Blood 104(6):1745-1752. https://doi.org/10.1182/blood-2004-02-0534

35. Michno A, Bielarczyk H, Pawelczyk T, Jankowska-Kulawy A, Klimaszewska J, Szutowicz A (2007) Alterations of adenine nucleotide metabolism and function of blood platelets in patients with diabetes. Diabetes 56(2):462-467. https://doi.org/10.2337/ db06-0390

36. Pereira ADS, de Oliveira LS, Lopes TF, Baldissarelli J, Palma TV, Soares MSP, Spohr L, Morsch VM, de Andrade CM, Schetinger MRC, Spanevello RM (2018) Effect of gallic acid on purinergic signaling in lymphocytes, platelets, and serum of diabetic rats. Biomed Pharmacother 101:30-36. https://doi.org/10.1016/j. biopha.2018.02.029

37. Stefanello N, Schmatz R, Pereira LB, Cardoso AM, Passamonti S, Spanevello RM, Thome G, de Oliveira GMT, Kist LW, Bogo MR, Morsch VM, Schetinger MRC (2016) Effects of chlorogenic acid, caffeine and coffee on components of the purinergic system of streptozotocin-induced diabetic rats. J Nutr Biochem 38:145-153. https://doi.org/10.1016/j.jnutbio.2016.08.015

38. Schmatz R, Mann TR, Spanevello R, Machado MM, Zanini D, Pimentel VC, Stefanello N, Martins CC, Cardoso AM, Bagatini M, Gutierres J, Leal CA, Pereira LB, Mazzanti C, Schetinger MR, Morsch VM (2013) Moderate red wine and grape juice 
consumption modulates the hydrolysis of the adenine nucleotides and decreases platelet aggregation in streptozotocin-induced diabetic rats. Cell Biochem Biophys 65(2):129-143. https://doi.org/ 10.1007/s12013-012-9407-5

39. Miron VR, Bauermann L, Morsch AL, Zanin RF, Correa M, da Silva AC, Mazzanti C, Morsch VM, Lunkes GI, Schetinger MR (2007) Enhanced NTPDase and 5'-nucleotidase activities in diabetes mellitus and iron-overload model. Mol Cell Biochem 298(1-2):101-107. https://doi.org/10.1007/s11010-006-9357-6

40. Lunkes GI, Lunkes DS, Morsch VM, Mazzanti CM, Morsch AL, Miron VR, Schetinger MR (2004) NTPDase and 5'-nucleotidase activities in rats with alloxan-induced diabetes. Diabetes Res Clin Pract 65(1):1-6. https://doi.org/10.1016/j.diabres.2003.11.016

41. Lunkes GI, Lunkes D, Stefanello F, Morsch A, Morsch VM, Mazzanti CM, Schetinger MR (2003) Enzymes that hydrolyze adenine nucleotides in diabetes and associated pathologies. Thromb Res 109(4):189-194. https://doi.org/10.1016/s0049-3848(03)00178-6

42. Lunkes GI, Lunkes DS, Leal D, Araujo Mdo C, Correa M, Becker L, Rosa CS, Morsch VM, Schetinger MR (2008) Effect of high glucose levels in human platelet NTPDase and 5'-nucleotidase activities. Diabetes Res Clin Pract 81(3):351-357. https://doi.org/ 10.1016/j.diabres.2008.06.001

43. Barr JD, Chauhan AK, Schaeffer GV, Hansen JK, Motto DG (2013) Red blood cells mediate the onset of thrombosis in the ferric chloride murine model. Blood 121(18):3733-3741. https:// doi.org/10.1182/blood-2012-11-468983

44. Ohman J, Kudira R, Albinsson S, Olde B, Erlinge D (2012) Ticagrelor induces adenosine triphosphate release from human red blood cells. Biochem Biophys Res Commun 418(4):754-758. https://doi.org/10.1016/j.bbrc.2012.01.093

45. Cattaneo M, Schulz R, Nylander S (2014) Adenosine-mediated effects of ticagrelor: evidence and potential clinical relevance. J Am Coll Cardiol 63(23):2503-2509. https://doi.org/10.1016/j. jacc.2014.03.031

46. Johnston-Cox HA, Yang D, Ravid K (2011) Physiological implications of adenosine receptor-mediated platelet aggregation. J Cell Physiol 226(1):46-51. https://doi.org/10.1002/jcp.22379

47. Ahmed YM, Anwar B, El-Daly ME, Abo-Saif AA (2019) Effects of ticagrelor, empagliflozin and tamoxifen against experimentallyinduced vascular reactivity defects in rats in vivo and in vitro. Pharmacol Rep 71(6):1034-1043. https://doi.org/10.1016/j. pharep.2019.06.004

48. Mangiacapra F, Panaioli E, Colaiori I, Ricottini E, Lauria Pantano A, Pozzilli P, Barbato E, Di Sciascio G (2016) Clopidogrel versus ticagrelor for antiplatelet maintenance in diabetic patients treated with percutaneous coronary intervention: results of the CLOTILDIA study (Clopidogrel High Dose Versus Ticagrelor for Antiplatelet Maintenance in Diabetic Patients). Circulation 134(11):835-837. https://doi.org/10.1161/CIRCULATIONAHA. 116.023743

49. Bhatt DL, Steg PG, Mehta SR, Leiter LA, Simon T, Fox K, Held C, Andersson M, Himmelmann A, Ridderstrale W, Chen J, Song Y, Diaz R, Goto S, James SK, Ray KK, Parkhomenko AN, Kosiborod MN, McGuire DK, Harrington RA, Committee TS, Investigators, (2019) Ticagrelor in patients with diabetes and stable coronary artery disease with a history of previous percutaneous coronary intervention (THEMIS-PCI): a phase 3, placebo-controlled, randomised trial. Lancet 394(10204):1169-1180. https:// doi.org/10.1016/S0140-6736(19)31887-2

Publisher's note Springer Nature remains neutral with regard to jurisdictional claims in published maps and institutional affiliations.

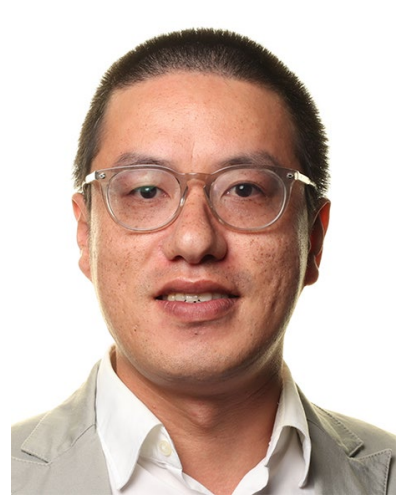

Zhichao Zhou is Assistant Professor of Division of Cardiology, Department of Medicine Solna at Karolinska Institutet, Sweden. He obtained his $\mathrm{PhD}$ in 2013 at the Erasmus University Medical Center Rotterdam, the Netherlands. He worked as a post-doctorate research fellow at the West Virginia University in USA (2014-2015) and Karolinska Institutet in Sweden (20152018). His research goals are to elucidate the novel disease mechanisms underlying cardiovascular complications and ultimately find the effective therapies. His current focus is on the role of erythrocyte as disease mediator of cardiovascular dysfunction in various cardiovascular and metabolic disorders. 